\title{
Respiratory sequelae of whooping cough
}

\author{
SWANSEA RESEARCH UNIT OF THE ROYAL COLLEGE OF GENERAL PRACTITIONERS
}

\begin{abstract}
Eight hundred and thirteen children who had had whooping cough when under 5 years of age in the 1977-9 epidemic were compared with a control group roughly four and a half years later, each child being matched by age and sex and from the same class in school. The index group showed long term respiratory sequelae of whooping cough-namely, deterioration in lung function, increase in respiratory symptoms, and increased admission to hospital for both upper and lower respiratory conditions. Asthma was significantly more common in the index group, suggesting that asthma was being regarded as a contraindication to pertussis vaccination. Only $3.5 \%$ of the asthmatic children in the index group had been vaccinated as against $29 \cdot 1 \%$ of the controls.
\end{abstract}

\section{Introduction}

Before the early part of this century whooping cough was one of the commonest causes of death in children.' Most of the deaths were due to bronchopneumonia caused by secondary infection. A serious long term effect was bronchiectasis, occurring as a consequence of unresolved atelectasis at the time of the whooping cough. ${ }^{2 \cdots 4}$ These serious pulmonary complications, however, have become much rarer since the introduction of antibiotics, which combat the secondary infection but have little effect on the whooping cough itself." Until recently we did not know whether whooping cough, as it occurs today,

\section{University College of Swansea}

Members of the research group were: Dr W O Williams (director); Dr R I Gilbert (statistical adviser), department of genetics; Mrs M Bodger (programmer), computer department; Miss L Burrell-Davis (programmer), department of sociology.

Correspondence and requests for reprints to: $\mathrm{Dr} W \mathrm{O}$ Williams, Director, RCGP Swansea Research Unit, Room 244, North Arts, University College of Swansea, Swansea SA2 8PP. still has any long term respiratory sequelae. Johnson et al carried out a study on 360 primary school children with a history of whooping cough and compared them with 711 matched controls who had not had whooping cough. Although no difference was found in the lung function of the two groups, respiratory symptoms were more common among the children with a history of whooping cough. ${ }^{7}$

We describe a study designed to test the hypothesis that "whooping cough causes respiratory sequelae in some children." The index cases for the study were taken from patients included in the 1977-9 study of whooping cough in West Glamorgan. ${ }^{8}$

\section{Method}

The study followed the same time sequence as the original epidemic, each patient with a history of whooping cough (index case) being seen roughly four and a half years from the time of onset of the whooping cough. The index group consisted of all children who were aged under 12 months at onset, all the rest under 5 years who had complications, and a one in three sample of the remainder-a total of 813 children. Each index case was matched by age and sex with a child in the same class in school but not more than four months each side of the birth date of the index case. A health questionnaire was completed by one of three nurses, first at the home of an index case and then at the home of a possible control, who was accepted if he or she had not had whooping cough. If all possible controls had been exhausted the index case was left out of the study. The children were then examined in school by a different nurse, who was unaware of their identity. Each child's height and weight were taken wearing indoor clothes, without shoes. Forced expiratory volume in one second $\left(\mathrm{FEV}_{1}\right)$ and forced vital capacity (FVC) were measured in litres using a McDermott spirometer. Seven satisfactory "blows" were recorded. Each instrument was tested and calibrated before each session and corrected for temperature before each child was examined. Testing sessions were carried out by pairs of testers, one acting as an observer. The child nearest in age to the index child was taken as a control and not a "more cooperative child" suggested by the teacher.

Statistical methods-Comparisons of frequencies were made by $\chi^{2}$ tests. For $2 \times 2$ tables, used in the analysis of history of illnesses, we followed the recommendations of Conover ${ }^{9}$ and of Sokal and Rohlf ${ }^{10}$ and did not correct $\chi^{2}$ for continuity; also we conducted several simulation studies, which indicated no need for a continuity correction. Adjusted residual analysis ${ }^{11}$ was employed to analyse numbers of children per household. 


\section{Results}

The response rate to the questionnaires was $99.5 \%$. Only $6.7 \%$ of the index children compared with $30.2 \%$ of the controls had been fully vaccinated against pertussis (area health authority data). Table I gives the mean ages of the index and control groups, sizes of households, and prevalence of smoking, and table II gives the social class distribution. The index and control cases were checked for matching in addition to the initial matching process.

TABLE I-Mean ages of study groups, sizes of households, and prevalence of smoking

\begin{tabular}{lcc}
\hline & Index group & Control group \\
\hline Total No of children studied & 813 & 813 \\
Mean ages of children studied (days) & $2008 \cdot 123$ & $2191 \cdot 6 *$ \\
Total No of people in households & 3597 & 3581 \\
Average No of people per household & $4 \cdot 43$ & $4 \cdot 40$ \\
Total No ( of of smokers in households & $660(18 \cdot 3)$ & $667(18 \cdot 6)$ \\
Percentage of parents who smoked & $76 \cdot 7$ & $76 \cdot 9$ \\
\hline
\end{tabular}

$t=1.02 ;$ two tailed test of probability: $\mathrm{p}=0.388$

TABLE II-Social class distribution of index and control children

\begin{tabular}{lcccc}
\hline \multicolumn{1}{c}{ Social class } & No $\left({ }_{0}{ }_{0}\right)$ of index cases & No $\left({ }^{\circ}\right)$ of controls \\
\hline II & 52 & $(6 \cdot 4)$ & 47 & $(5 \cdot 8)$ \\
II & 152 & $(18 \cdot 7)$ & 128 & $(15 \cdot 7)$ \\
III $\{$ Skilled non-manual & 63 & $(7 \cdot 7)$ & 86 & $(10 \cdot 6)$ \\
IV Skilled manual & 404 & $(49 \cdot 7)$ & 437 & $(53 \cdot 8)$ \\
V & 46 & $(5 \cdot 7)$ & 31 & $(3 \cdot 8)$ \\
Not known & 61 & $(7 \cdot 5)$ & 58 & $(7 \cdot 1)$ \\
\multicolumn{1}{c}{ Total } & 35 & $(4 \cdot 3)$ & 26 & $(3 \cdot 2)$ \\
\hline
\end{tabular}

\section{PAIR MATCHING}

The difference in ages (in days) between the index and control children was tested by paired $t$ test and found to be not significant (table I). The age distribution of non-sampled children in the households, however, was significant $\left(\chi^{2}=15 \cdot 266 ; \mathrm{df}=3\right)$, there being more children aged 10-14 years in the control households $(10.6 \%)$ than in the index households $(8 \cdot 7 \%$ ) but fewer children aged 5-9 years in the control households $\left(30.0^{\circ}, v 33.6 \%\right.$ ) (table III). The reason was not clear. There was no significant difference between each social class $\left(\chi^{2}=11 \cdot 572 ; \mathrm{df}=6\right.$; table II).

TABLE III-Age pattern of households in index and control groups

\begin{tabular}{ccc}
\hline $\begin{array}{c}\text { Age groups } \\
\text { (years) }\end{array}$ & $\begin{array}{c}\text { No (\%) of members in } \\
\text { index households }\end{array}$ & \multicolumn{2}{c}{$\begin{array}{c}\text { No (\%) of members in } \\
\text { control households }\end{array}$} \\
\hline$\geqslant 15$ & $1699(47 \cdot 2)$ & $1741(48 \cdot 6)$ \\
$10-14$ & $312(8 \cdot 7)$ & $381(10 \cdot 6)$ \\
$5-9$ & $1210(33 \cdot 6)$ & $1076(30 \cdot 0)$ \\
$0-4$ & $376(10 \cdot 5)$ & $383(10 \cdot 7)$ \\
\hline Total & $3597(100 \cdot 0)$ & $3581(100 \cdot 0)$ \\
\hline
\end{tabular}

\section{PAST ILLNESSES AND PRESENT RESPIRATORY SYMPTOMS}

Measles, chickenpox, acute bronchitis, pneumonia, hard of hearing, ear infection, hay fever, eczema, and asthma were all significantly more common among the index children than the controls. In particular, $85(10.5 \%)$ of the index children had asthma compared with only $55(6.8 \%)$ of the controls $(p=0.006)$. Mumps, convulsions, meningitis, and serious mental subnormality showed no significant differences. Of the asthmatics, only three $(3.5 \%)$ in the index group had been fully vaccinated compared with $16\left(29 \cdot 1{ }^{\circ}\right)$ of the controls; this difference was very highly significant $\left(\chi^{2}=18 \cdot 15 ; \mathrm{df}=1\right)$.

For each respiratory symptom except the first listed in table IV there was a significant excess of index cases. When children with a personal or family history of asthma were excluded (table IV) symptoms 2,3 , and 6 remained highly significant $(p<0.001)$. Symptoms 4 , 5 , and 8 became non-significant, and for symptoms 7 and 9 significance was reduced from $1 \%$ to nearer $5 \%$.

CONDITIONS NEEDING HOSPITAL ADMISSION OR OUTPATIENT ATTENDANCE

The number of admissions for both upper and lower respiratory conditions was the same in the two groups before whooping cough in the index cases but significantly greater in the index group after whooping cough (table V). When children with a personal or family history of asthma, eczema, or hay fever were excluded there remained a significant excess of index cases $\left(26 ; 66.7^{\circ}{ }_{0}\right)$ over controls (13; $33.3^{\circ}$ ) who had had their tonsils or adenoids, or both, removed after whooping cough. This was also the case with ear, nose, and throat conditions in general- $46\left(76 \cdot 8^{\circ}\right)$ of the index cases compared with $25\left(25.4^{\circ}\right)$ of the controls. Sixteen of the index children were seen as outpatients for asthma after whooping cough $(p<0.05)$. There were 13 index children with ear infections compared with only three controls ( $p=0.0213$ using the binomial distribution). Children

TABLE $\mathrm{v}-$ Reasons for hospital admissions and outpatient attendances in index and control groups. Figures are numbers of children

\begin{tabular}{|c|c|c|c|c|}
\hline & \multicolumn{2}{|c|}{$\begin{array}{c}\text { Before } \\
\text { whooping cough }\end{array}$} & \multicolumn{2}{|c|}{$\begin{array}{c}\text { After } \\
\text { whooping cough }\end{array}$} \\
\hline & $\begin{array}{l}\text { Index } \\
\text { cases }\end{array}$ & Controls & $\begin{array}{l}\text { Index } \\
\text { cases }\end{array}$ & Controls \\
\hline \multicolumn{5}{|c|}{ Admissions } \\
\hline $\begin{array}{l}\text { Upper respiratory condition } \\
\text { Removal of tonsils or adenoids } \\
\text { Insertion of grommets } \\
\text { Infections of middle ear, tonsils, or }\end{array}$ & $2_{2}^{8}$ & $4^{4}$ & $\begin{array}{l}47^{66} \\
12\end{array}$ & $24^{33^{*}}$ \\
\hline $\begin{array}{l}\text { sinuses } \\
\text { Lower respiratory condition } \\
\text { Pneumonia } \\
\text { Bronchitis } \\
\text { Asthma }\end{array}$ & $\begin{array}{l}4 \\
7 \\
75 \\
4\end{array}$ & $\begin{array}{c}2 \\
7^{2} \\
16 \\
4\end{array}$ & $\begin{array}{c}7 \\
9^{33} \\
9 \\
15\end{array}$ & $\begin{array}{l}4 \\
2^{14^{*}} \\
4 \\
8\end{array}$ \\
\hline \multicolumn{5}{|c|}{ Outpatient attendances } \\
\hline $\begin{array}{l}\text { All conditions } \\
\text { Investigation for deafness } \\
\text { Middle ear infection } \\
\text { Recurrent tonsillitis } \\
\text { Sinusitis and adenoiditis } \\
\text { Asthma } \\
\text { Bronchitis }\end{array}$ & $\begin{array}{l}0^{3} \\
0 \\
1 \\
0 \\
0 \\
2 \\
2\end{array}$ & $\begin{array}{l}0^{2} \\
0 \\
0 \\
1 \\
0 \\
1\end{array}$ & $\begin{array}{l}21 \\
13 \\
7 \\
0 \\
16 \\
4\end{array}$ & $\begin{array}{c}29 \\
10^{29} \\
3 \\
9 \\
2 \\
2 \\
3\end{array}$ \\
\hline
\end{tabular}

*After recovery from whooping cough in matched index case

(arrent respiratory symptoms in index and control children. Results expressed as number (and percentage) of children whose parents answered "yes" to any of nine questions on symptoms

\begin{tabular}{|c|c|c|c|c|c|c|}
\hline \multirow{2}{*}{ Question } & \multicolumn{2}{|c|}{$\begin{array}{l}\text { (A) Children with asthma or } \\
\text { family history of asthma INCLUDED }\end{array}$} & \multicolumn{2}{|c|}{$\begin{array}{l}\text { Statistical } \\
\text { significance }\end{array}$} & \multicolumn{2}{|c|}{$\begin{array}{l}\text { (B) Children with asthma or } \\
\text { family history of asthma EXCLUDED }\end{array}$} \\
\hline & Index cases & Controls & (A) & (B) & Index cases & Controls \\
\hline \multirow{4}{*}{$\begin{array}{l}\text { (1) Does your child cough with colds ? } \\
\text { (2) Does your child cough without colds ? } \\
\text { (3) If there are other children under } 10 \text { in the house, does } \\
\text { your child cough more than these? } \\
\text { (4) Does your child's chest ever sound wheezy ? } \\
\text { (5) Is your child wheezy after exercise without a cold ? } \\
\text { (6) Is your child's wheeze worse at night even without a cold? } \\
\text { (7) Has your child had any attacks of shortness of breath or } \\
\text { wheezing? } \\
\text { (8) If yes, is your child all right between attacks? } \\
\text { (9) Does your child get more breathless than other children of } \\
\text { the same age while playing and running about? }\end{array}$} & $\begin{array}{l}613(75 \cdot 4) \\
191(23.5)\end{array}$ & $\begin{array}{l}561(69 \cdot 0) \\
120(14 \cdot 8)\end{array}$ & $\mathrm{p}<0.001$ & $\begin{array}{l}p<0.05 \\
p<0.001\end{array}$ & $\begin{array}{l}532(65 \cdot 4) \\
150(18 \cdot 5)\end{array}$ & $\begin{array}{r}512(63 \cdot 0) \\
98(12 \cdot 1)\end{array}$ \\
\hline & $\begin{array}{r}186(22.9) \\
258(31 \cdot 7) \\
68(8.4) \\
68(8.4)\end{array}$ & $\begin{array}{r}90(11 \cdot 1) \\
216(26 \cdot 6) \\
42(5 \cdot 2) \\
28(3 \cdot 4)\end{array}$ & $\begin{array}{l}p<0.001 \\
p<0.05 \\
p<0.05 \\
p<0.001\end{array}$ & $\begin{array}{c}\mathrm{p}<0.001 \\
\text { NS } \\
\text { NS } \\
\mathrm{p} \\
0.001\end{array}$ & $\begin{array}{r}145(17 \cdot 8) \\
184(22 \cdot 6) \\
21(2 \cdot 6) \\
25(3 \cdot 1)\end{array}$ & $\begin{array}{r}73(9 \cdot 0) \\
164(20 \cdot 2) \\
15(1.8) \\
6(0.7)\end{array}$ \\
\hline & $\begin{array}{ll}75 & (9 \cdot 2) \\
61 & (7 \cdot 5)\end{array}$ & $\begin{array}{ll}43 & (5 \cdot 3) \\
40 & (4 \cdot 9)\end{array}$ & $\begin{array}{l}p<0.01 \\
p<0.05\end{array}$ & $\mathrm{p} \underset{\mathrm{NS}}{0.05}$ & $\begin{array}{ll}21 & (2 \cdot 6) \\
17 & (2 \cdot 1)\end{array}$ & $\begin{array}{ll}9 & (1 \cdot 1) \\
9 & (1 \cdot 1)\end{array}$ \\
\hline & $73(9 \cdot 0)$ & $38 \quad(4 \cdot 7)$ & $p<0.01$ & $p<0.005$ & $25 \quad(3 \cdot 1)$ & $14 \quad(1 \cdot 7)$ \\
\hline
\end{tabular}

*NS $=$ Not significant 
seen as outpatients for respiratory conditions after whooping cough in the index cases numbered 61 in the index group and 29 controls $(\mathrm{p}<0.001)$

\section{HEIGHT, WEIGHT, AND LUNG FUNCTION}

The mean heights and weights of each group did not differ significantly even in individual age groups. The mean of the best three readings of $\mathrm{FEV}_{1}$ and $\mathrm{FVC}$ was used for the analysis. ${ }^{12}$ Firstly, the crude mean $\mathrm{FEV}_{1}$, mean FVC, and $\mathrm{FEV}_{1} \times 100 /$ mean FVC (not corrected for height) were compared between the index and control cases, and the average of these figures showed no significant difference. Nevertheless, when the data were corrected for height $\left(\mathrm{HT}^{2}\right)^{13}$ as well as analysing by age groups a more interesting picture emerged. This is important because whooping cough was worse in the younger children. Since we had matched pairs the corrected control lung function value was subtracted from the corrected index value in each pair and a single sample $t$ test carried out on these differences multiplied by 1000 to minimise rounding error. Table VI gives the results, $L_{1}, L_{2}, L_{3}$, and $L_{4}$ referring to each difference in the table. time" was about three times that of children diagnosed as having asthma. Asthma is reportedly underdiagnosed in the community, ${ }^{24}{ }^{25}$ possibly because of the difficulty in diagnosis, ${ }^{26}$ distinguishing it from other forms of wheezing, and partly due to a reluctance to use the label "asthma." Doctors may be including a personal or family history of asthma as a contraindication to vaccination. The vaccination rate in the index group with asthma was only $3.5 \%$ compared with $29.1 \%$ for the controls. Hull ${ }^{27}$ has shown that there is a good deal of uncertainty about how the recommended contraindications ${ }^{2 *}$ should be interpreted. Unvaccinated children are more likely to develop whooping cough, and this may explain the excess of asthmatics in the index group. Another possible relation between asthma and whooping cough has been shown in animals, which become particularly sensitive to respiratory stimulants when injected with live or killed Bordetella pertussis. They become hypersensitive to serotonin, bradykinin, acetylcholine, and histamine. ${ }^{29}$ The infection induces a hyperactive bronchial state to non-specific stimuli. A block to the $\beta_{.2}$

TABLE VI-Differences in lung function values between index and control children corrected for height. Results expressed as index value minus control value (differences multiplied by 1000 to convert to integers)

\begin{tabular}{|c|c|c|c|c|c|c|c|c|c|}
\hline \multirow[b]{2}{*}{ Age (years) } & \multirow[b]{2}{*}{ df } & \multicolumn{2}{|c|}{$\mathrm{L}_{1}\left(\right.$ maximal $\left.\mathrm{FEV}_{1} / \mathrm{HT}^{2}\right)$} & \multicolumn{2}{|c|}{$\mathrm{L}_{2}\left(\right.$ mean $\left.\mathrm{FEV}_{1} / \mathrm{HT}^{2}\right)$} & \multicolumn{2}{|c|}{$\mathrm{L}_{3}\left(\right.$ maximal $\left.\mathrm{FVC} / \mathrm{HT}^{2}\right)$} & \multicolumn{2}{|c|}{$\mathrm{L}_{4}\left(\right.$ mean $\left.\mathrm{FVC} / \mathrm{HT}^{2}\right)$} \\
\hline & & Mean & $t$ & Mean & $t$ & Mean & $t$ & Mean & $t$ \\
\hline $\begin{array}{l}4 \\
5 \\
6 \\
7 \\
8 \\
9\end{array}$ & $\begin{array}{r}79 \\
156 \\
130 \\
168 \\
180 \\
65\end{array}$ & $\begin{array}{r}-26.2625 \\
-13.1529 \\
-13.1579 \\
-11.2024 \\
+2.7527 \\
-1.7576\end{array}$ & $\begin{array}{l}-0.9339 \\
-0.8726 \\
-1.0215 \\
-0.9820 \\
+0.2633 \\
-0.0854\end{array}$ & $\begin{array}{r}-24.9365 \\
-18.6242 \\
-15.8092 \\
-16.4734 \\
+0.7912 \\
+0.9697\end{array}$ & $\begin{array}{l}-0.8767 \\
-1.2013 \\
-1.2186 \\
-1.2716 \\
+0.0755 \\
+0.0470\end{array}$ & $\begin{array}{r}-15.2500 \\
-18.7962 \\
-15.7820 \\
-10.0473 \\
+4.8571 \\
+3.6515\end{array}$ & $\begin{array}{l}-0.5037 \\
-1.0948 \\
-1.1539 \\
-0.8496 \\
+0.4405 \\
+0.1552\end{array}$ & $\begin{array}{r}-20.9375 \\
-21.3248 \\
-17.7273 \\
-16.8988 \\
+5.3132 \\
+6.6667\end{array}$ & $\begin{array}{r}-0.6584 \\
-1.2556 \\
-1.2979 \\
-1.2090 \\
+0.4951 \\
+0.2913\end{array}$ \\
\hline All & & -9.4313 & -1.5582 & $-12 \cdot 1860$ & -1.9457 & -8.6950 & -1.3230 & $-11 \cdot 2038$ & -1.6519 \\
\hline
\end{tabular}

-Statistically significant.

In age groups 4-7 inclusive the $t$ value for each $L$ result was comparatively large and negative, although none was conventionally significant, supporting the idea that whooping cough is more severe in younger children. The $t$ values in age groups 8 and 9 were all very small, but these children had been older when they contracted the disease. It therefore seemed justifiable to repeat the tests on the younger children up to age 7 inclusive (table VI). $\mathrm{L}_{2}$ and $\mathrm{L}_{4}$ were significant, and although $\mathrm{L}_{1}$ and $\mathrm{L}_{3}$ were almost significant they are not as important as $\mathrm{L}_{2}$ and $\mathrm{L}_{4}$.

One hundred and sixty of the index children $(19.7 \%)$ had had important respiratory complications at the time of whooping coughnamely, asthma (7), haemoptysis (1), acute bronchitis (115), pneumonia (14), atelectasis (4), and apnoea (19). Lung function values, however, were within normal limits, even in the asthmatics, in whom there was no evidence of airways obstruction. Nevertheless, we could not be sure if any had received treatment on the day of the test, despite asking the parents to let us know.

\section{Discussion}

In view of the considerable controversy about the possible risks ${ }^{14-18}$ and benefits ${ }^{19-22}$ of pertussis vaccine it was essential to carry out this study with as little bias as possible. Despite our care in interviewing we could not be completely certain that some of our controls had not had whooping cough because the diagnosis of mild cases may sometimes be missed. The response rate from the parents was very good, far better than would have been attained by a postal questionnaire. Also, we find that using a small number of well trained observers engenders interest and achieves a higher standard of recording. ${ }^{23}$

In agreement with Johnson et al, we found that the group with a history of whooping cough had more respiratory symptoms than controls. ${ }^{7}$ We also found that more of the index children than controls were admitted to hospital and seen as outpatients for respiratory conditions even after the exclusion of children with a personal or family history of asthma. The number of children in the study who "wheezed from time to adrenergic receptors probably occurs in asthma, and the same mechanism may occur in whooping cough and may even lead to asthma. ${ }^{30}$

The relevance of coughing without colds in the index group was intriguing. $B$ pertussis is known to attack the ciliated columnar epithelium of the respiratory tract. This mucus membrane in ferrets infected with the influenza virus recovers in about three weeks ( $\mathrm{Sir}$ Charles Stuart-Harris, personal communication, 1984), but it may not when the basement membrane is destroyed. Lymphoid tissue of the adenoids may become hypertrophied due to infection with a mixed flora of bacteria after the prolonged illness of whooping cough, providing a permanent reservoir of infection for the eustachian tube and middle ear-a common cause of secretory otitis media and deafness in children. Arguably, ear, nose, and throat conditions were more common among the index children because of their higher prevalence of "allergic" conditions. Removal of these children, however, made no difference to the significant excess in the index cases over controls. We know from the 1977-9 epidemic that the younger the child the more serious will be the illness.

In contrast to Johnson et al, ${ }^{7}$ we found a small but real difference in performance in lung function tests between index and control children up to and including the age of 7 but no difference thereafter. This was even after excluding children with a personal or family history of asthma, leaving whooping cough as the most likely cause of their poorer lung function. Only four children of our index group were known to have suffered from atelectasis in the 1977-9 West Glamorgan study, but their lung function was now normal. Lees reported 65 cases of atelectasis $(43.0 \%$ ) among patients admitted to a Glasgow hospital with whooping cough during 1946 and $1947 . .^{2}$ More recently in Australia $46.0 \%$ of children admitted to hospital with whooping cough had various degrees of atelectasis. ${ }^{31}$ Only $2.8 \%$ of our children had been treated in hospital, and the rest, treated at home, would not have been afforded a careful pul- 
monary radiological scrutiny as in hospital. We would therefore not know if any of these children had small areas of collapse, which could not be detected clinically and had not cleared up completely, giving them a permanently reduced FVC. It might be argued that the younger the child the greater would be his difficulty in understanding how to do the lung function test. Although it took more patience with the younger ones, we succeeded in testing satisfactorily all but 64 children. We found that the lung function of the index children who had had respiratory complications after whooping cough in the 1977-9 epidemic was within normal limits. There were no children with evidence of bronchiectasis.

We thank the three research nurses, Mrs A Cunningham, Mrs A C Roberts, and Mrs M Wilson, and the two unit secretaries, Mrs A Griffiths and Mrs P Saunders, for their unfailing efforts to make this study a success; Mrs P McCarthy and Mrs M McDermott, of the Medical Research Council Pneumoconiosis Research Unit at Llandough Hospital, Penarth, for their guidance in the method of lung function testing; and Mrs M F Clay for teaching the nurses to use the spirometer and for repairing the instruments when these became faulty. We also thank Dr P D Oldham, chairman of the executive committee of the MRC Pneumoconiosis Unit, Penarth, for his invaluable help during the study and detailed comments on the main report. Finally, this unit is grateful to the Department of Health and Social Security for the generous grant, without which this study would not have been possible.

\section{References}

1 Osler $\mathrm{W}$. Whooping cough. In: The principle and practice of medicine. New York, London: D Appleton and Company, 1918

Lees AW. Atelectasis and bronchiectasis in pertussis. Br Med 7 1950;ii:1138-41

Nicholson DP. Pulmonary collapse in pertussis. Arch Dis Child 1949;24:29-40. ames U, Brimblecombe FSW, Weston Wells J. The natural his
collapse in childhood. Q $\mathcal{F}$ Med 1956;97(NS XXV):121-36.
6 Islur J, Anglin CS, Middleton PJ. The whooping cough syndrome: a continuing pediatric problem. Clin Pediatr (Phila) 1975;14:171-6.

7 Johnson IDA, Lambert HP, Anderson HR, Patel S. Respiratory morbidity and lung function after whooping cough. Lancet 1983;ii:1104-8.

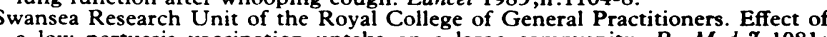
a low pert $282: 23-32$.

Conover WJ. Some reasons for not using the Yates continuity correction on $2 \times 2$ contingency tables. Fournal of the American Statistical Association 1974 69:374. 10 Sokal RR, Rohlf FJ. Biometry. 2nd ed. San Francisco: W H Freeman and Co,

11 Cox DR, Snell EJ. A general definition of residual. fournal of the Royal Statistical

Society $B$ 1968;30:248.
12 Oldham PD, Cole TJ. Estimation of the FEV,. Thorax 1983;38:662-7 Cole TJ. Linear and proportional regression models in the prediction of ventilatory function. Fournal of the Royal Statistical Society $A$ 1975;138:297-338. pertussis inoculation. Arch Dis Child 1974:49:46-9.

Jeavons PM. Whooping cough immunisation policy. Lancet 1975;ii:811.

16 Stewart GT. Reactions to pertussis vaccine. Lancet 1983;i:1217-8.

17 Stewart GT. Pertussis vaccine-benefits and risks. N Engl f Med 1980;302. 634 .

18 Stewart GT. Benefits and risks of pertussis vaccine. N Engl F Med 1980;303: 1004

19 Department of Health and Social Security, Joint Committee on Vaccination and Immunisation. Review of the evidence on whooping cough vaccination. London: HMSO, 1977.

20 Joint Committee on Vaccination and Immunisation of the Central Health Service Council and the Scottish Health Service Council and the Scottish
Health Service Planning Council. Whooping cough vaccine. Br Med $\mathcal{J} 1975$; iii : 687

21 Noah ND. Attack rates of notified whooping cough in immunised and unimmunised children. Br Med $\mathcal{f} 1976 ; 1: 128$.

22 McKendrick MW, Gulley PR, Geddes AM. Protection against pertussis by immunisation. $\mathrm{Br}$ Med f $1980 ; 281: 1390-1$.

23 Williams WO. How to do collaborative research $B r$ Med f 1982;285:480-2.

4 Speight ANP, Lee DA, Hey EN. Underdiagnosis and undertreatment of asthma in childhood. $B r$ Med $71983 ; 286: 1253-6$

25 Lee DA, Winslow NR, Speight ANP, Hey EN. Prevalence and spectrum of

Gregg I. Epidemiological aspects. In: Clarke TJH, Godfrey S, eds. Asthma. 2nd ed. London: Chapman and Hall, 1983:242-84

27 Hull $D$. Interpretation of the contraindications to whooping cough vaccination. Br Med f 1981;283:1231-3.

8 Department of Health and Social Security, Joint Committee on Vaccination and Immunisation. Immunisation against infectious disease. London: HMSO, 1984 9 Badr-El-Din MK, Aref GH, Mazloum H, et al. The beta-adrenergic receptors

in pertussis. F Trop Med Hyg 1976;79:213.
30 Szentivanyi A. The beta-adrenergic theory of the atopic abnormality of bronchial asthma. Fournal of Allergy 1968;42:202-32.

orsyth $\mathrm{K}$, Farmer $\mathrm{K}$, Lennon $\mathrm{BR}$. High admission rate of infants and young children with whooping cough
Aust Pediatr $f$ 1984;20:101-3.

(Accepted 4 April 1985)

\title{
Screening for Down's syndrome using serum $\alpha$ fetoprotein: a retrospective study indicating caution
}

\author{
K SPENCER, P CARPENTER
}

\begin{abstract}
A report was made on the outcome of a four year retrospective study in 27064 pregnancies, of the clinical efficiency, sensitivity, and specificity of a screening programme for Down's syndrome based on reported strategies related to the measurement of maternal serum $\alpha$ fetoprotein. This study identified 27 pregnancies affected by Down's syndrome with a median multiple of the median maternal serum $\alpha$ fetoprotein concentration of 0.82 . This figure is considerably higher than that obtained from previous reports on this subject. With an age related multiple of the median maternal serum a fetoprotein strategy, $30.8 \%$ of Down's affected pregnancies were identified as well as $11.6 \%$ of unaffected
\end{abstract}

\footnotetext{
Endocrinology Laboratory, Department of Biochemistry, Oldchurch Hospital, Romford, Essex

K SPENCER, MSC, MRSC, principal biochemist

P CARPENTER, FIMLS, chief medical laboratory scientific officer

Correspondence to: $\mathrm{Mr} \mathrm{K}$ Spencer.
}

pregnancies. Perhaps a United Kingdom collaborative study should begin to investigate the reasons for such wide population variance in the reports for the median multiple of the median for Down's affected pregnancies. Until such studies are carried out, screening for Down's syndrome based on low maternal serum $\alpha$ fetoprotein concentration is premature.

\section{Introduction}

Last year two reports were published outlining the possibility of screening for Down's syndrome, ${ }^{12}$ based on observations that in pregnancies affected by Down's syndrome the maternal serum $\alpha$ fetoprotein concentrations are lower than in unaffected pregnancies. Merkatz et al first showed a relation between fetal trisomic chromosomal abnormalities and low maternal serum $\propto$ fetoprotein concentrations among 41 affected cases compared with maternal serum $\alpha$ fetoprotein concentrations in a group of normal matched controls. ${ }^{1}$ Similarly Cuckle et al showed that in 61 Down's affected pregnancies the maternal serum $\alpha$ fetoprotein concentration, at 14-20 weeks' gestation was 0.72 multiple of the median for a series of 36652 singleton 